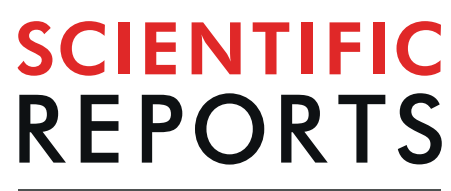

natureresearch

Check for updates

\title{
Non-mantle-plume process caused the initial spreading of the South China Sea
}

\begin{abstract}
Xun Yu \& Zhifei Liu
The mantle plume process is thought to be the prevailing dynamic mechanism for the South China Sea opening, but controversy persists due to the lack of critical evidence of magma in the initial seafloor spreading. International Ocean Discovery Program (IODP) Expedition 367 successfully recovered at Site U1500 the mid-ocean ridge basalt (MORB) representing the magma activity of the initial spreading of the South China Sea during the earliest Oligocene. Here we present the whole-rock and olivine phenocryst geochemistry of the basalts to constrain the potential influence of the Hainan mantle plume on the evolution of the South China Sea. Major and trace elemental compositions indicate that the basalts were mainly influenced by fractional crystallization of olivine and formed by melting of a spinel peridotite source without any pyroxenite in mantle source. The calculated mantle potential temperature of those most primitive basalts is much lower than plume-related MORB of Iceland, but similar to normal MORB elsewhere. Both lithological composition and mantle potential temperature clearly contradict with the mantle plume model, signifying that the mantle plume didn't exist at the earliest Oligocene. Therefore, the initial spreading of the South China Sea should be caused by nonplume processes, most likely by the westward subduction of the Pacific Plate.
\end{abstract}

Dynamic processes of continental breakup and subsequent initial generation of igneous oceanic crust have been identified as two end-members: magma-rich type and magma-poor type ${ }^{1,2}$. For the magma-rich type, the rifted margin is characterized by massive igneous activity in a relatively short period of time ( $\sim 1-3 \mathrm{Myr})$ during breakup and initial seafloor spreading, which is caused by mantle plume. The pair of conjugate margins of Greenland and northwest Europe is a typical example ${ }^{3}$. For the magma-poor type, weakening of mantle lithosphere and facilitating of plate rupture is caused by serpentinization over a period of time which is a result of tectonic extension and mantle exhumation. The Newfoundland and Iberia conjugate margin is a typical example ${ }^{4}$. However, the South China Sea (SCS) margin doesn't meet the expected characteristics of neither magma-rich nor magma-poor types, instead showing a rapid transformation from continental breakup to initial spreading without massive magmatism ${ }^{5}$. Revealing the formation process of such a unique type margin can help us understand the dynamic mechanism of the marginal sea evolution. Meanwhile, it also provides an important supplementary knowledge for the continental breakup and oceanic formation on the Earth.

Various models have been put forward to explain the formation of the SCS, such as tectonic extrusion by India-Eurasia collision ${ }^{6,7}$, extension related to mantle plume upwelling ${ }^{8-10}$, and regional extension by subduction and retreat of the Pacific plate ${ }^{11}$. Among them, the mantle plume is considered as the most popular model ${ }^{10,12-14}$. The evidence include: (1) seismic observations indicate a low-velocity zone beneath the SCS that extends to the lower mantle, supporting the existence of a deep plume ${ }^{15,16}$; (2) the mantle potential temperatures of Hainan ocean island basalts (OIB), as well as the olivine crystallization temperatures of mid-ocean ridge basalts (MORB) from the east sub-basin of the SCS, are similar to those of hotspot-related OIB and higher than those of normal MORB (N-MORB) ${ }^{12,17}$; (3) The EM2-like Sr, Nd, and Pb isotopic geochemistry of SCS OIB and MORB are consistent with the isotopic features of Hainan $\mathrm{OIB}^{13,14}$, which are considered to origin from a deep mantle plume ${ }^{18,19}$.

However, the MORB samples reported from Site U1431 (IODP Expedition 349) represent oceanic crust that formed toward the end of extension (16-15 Ma) of the SCS basin ${ }^{10,13,14,20}$. Intraplate basalts like Hainan OIB are much younger than the spreading cessation age of the SCS basin ${ }^{8}$. As a result, the thermal state and geochemical nature of mantle sources which were recovered from above samples cannot decide the role of Hainan plume in the early evolution history of the SCS basin. In addition, the recent drilling results suggest that the SCS basin 


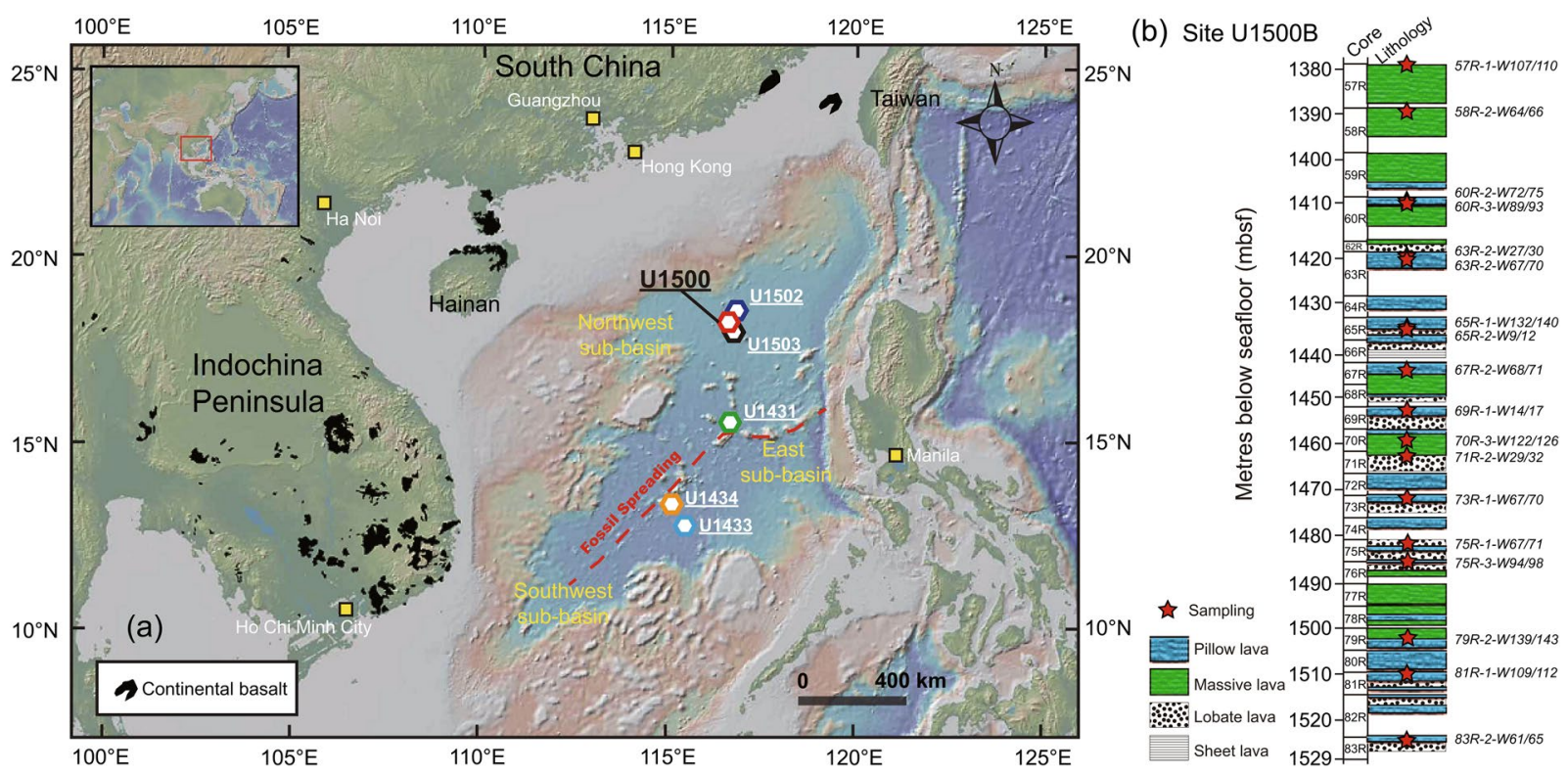

Figure 1. Topographic map of the South China Sea (SCS) and sampling location (a), and stratigraphy of recovered core (b). Locations of sites which drilled into basement rocks are shown. Sites U1431, U1433, and U1434 are from IODP Expedition $349^{22}$. Site U1500 is from IODP Expedition 367, Site U1502 is from IODP Expedition 368, and Site U1503 is from IODP Expedition $368 \mathrm{X}^{21,23}$. Distribution of Cenozoic intraplate volcanisms is also shown ${ }^{8}$. Figure (a) made with GeoMapApp 3.6.6 (www.geomapapp.org).

experienced a rapid transformation from continental breakup to igneous oceanic crust without abundant magmatism ${ }^{5}$. The above feature seems inconsistent with plume-induced opening model as characterized by excessive magmatism like magma-rich type margin in the North Atlantic ${ }^{5}$. Therefore, to determine whether the Hainan plume played an important role in opening of the SCS basin, obtaining the mantle potential temperature (Tp) of the upper mantle and understanding the mantle source lithology of basalts formed at the initial spreading stage is the key. In this study, major- and trace-element whole-rock and olivine phenocryst data are reported for the basalts of IODP Expedition 367 Site U1500. These basalts represent oceanic crust produced during the initial spreading of the SCS at $\sim 33 \mathrm{Ma}^{5,21}$. The geochemical data of Site U1500 basalts are used to determine the mantle source lithology and $T \mathrm{p}$ of the upper mantle that produced the basalts, as well as the role of the Hainan plume on the formation and evolution of the SCS basin.

The SCS is located at the junction of the Eurasian, Pacific, and Indo-Australian plates ${ }^{5,21-23}$ (Fig. 1a). The deep-water basin of the SCS can be divided into the east sub-basin, the southwest sub-basin, and the northwest sub-basin (Fig. 1a). Among them, the east sub-basin and southwest sub-basin are two main deep basins, which are separated by the N-S trending Zhongnan Fault ${ }^{22}$. The east sub-basin was formed by north-south spreading between 33-15.5 Ma and the southwest sub-basin was formed by northwest-southeast spreading between 24-16 $\mathrm{Ma}^{24}$. After the spreading cessation, intraplate volcanisms formed within and around the $\mathrm{SCS}^{8,25-27}$ (Fig. 1a). Four sites were drilled by IODP Expeditions 367 and 368 in the northern margin of the east sub-basin, one on the outer margin high and three seaward on the outer margin high basement ridges ${ }^{21}$. These ridges are within the continent-ocean transition zone going from outer margin high to the steady-state oceanic crust of the SCS. The seafloor in this region is thought to have formed at $\sim 32-30 \mathrm{Ma}$, the half-spreading rate of which was $\sim 3.6 \mathrm{~cm} / \mathrm{y}^{24}$. Site U1500 is the most seaward site (Fig. 1a), which can stand for the early stage of magmatism during seafloor spreading ${ }^{21} .149 .9 \mathrm{~m}$ of igneous rocks were cored below sedimentary section and a total of $114.92 \mathrm{~m}$ of basalt was recovered $^{21}$ (Fig. 1b). The basalts are divided into two igneous subunits according to flow boundaries to distinguish an upper massive lava flow sequence $(27.28 \mathrm{~m}$ thick) from a lower, predominantly pillow lava flow succession ( $122.62 \mathrm{~m}$ thick) with subordinate thin $(<6 \mathrm{~m})$ interbedded lobate, sheet, and massive lava flows. The pillow lobes are well preserved and are separated by chilled, glassy margins and also claystone ${ }^{28}$. Basalt samples remain similar in texture and mineralogical composition, varying from nonvesicular to moderately vesicular, cryptocrystalline to fine grained, and aphyric to highly (olivine-) plagioclase phyric with a hypocrystalline groundmass ${ }^{28}$. Plagioclase phenocrysts are found throughout these basalts with olivine being an occasional phenocryst, and rare clinopyroxene phenocrysts are identified (Supplementary Fig. S1a). The abundance of plagioclase and olivine phenocrysts increases downhole, reaching a peak of $20 \%$ to $35 \%$ for plagioclase and $5 \%$ to $10 \%$ for olivine ${ }^{28}$. In this study, 18 basalt samples were collected from Site U1500 and they are fresh in hand specimen and thin sections (Supplementary Fig. S1b).

\section{Geochemical results}

Site $\mathrm{U} 1500$ basalts are classified as tholeiitic basalts on an $\mathrm{Na}_{2} \mathrm{O}+\mathrm{K}_{2} \mathrm{O}$ versus $\mathrm{SiO}_{2}$ diagram, consistent with MORB elsewhere and with basalts from Sites U1431 and U1433 in the eastern and southwestern sub-basins of the SCS, respectively (Supplementary Fig. S2a). Site U1500 basalts are classified as normal MORB (N-MORB) and 

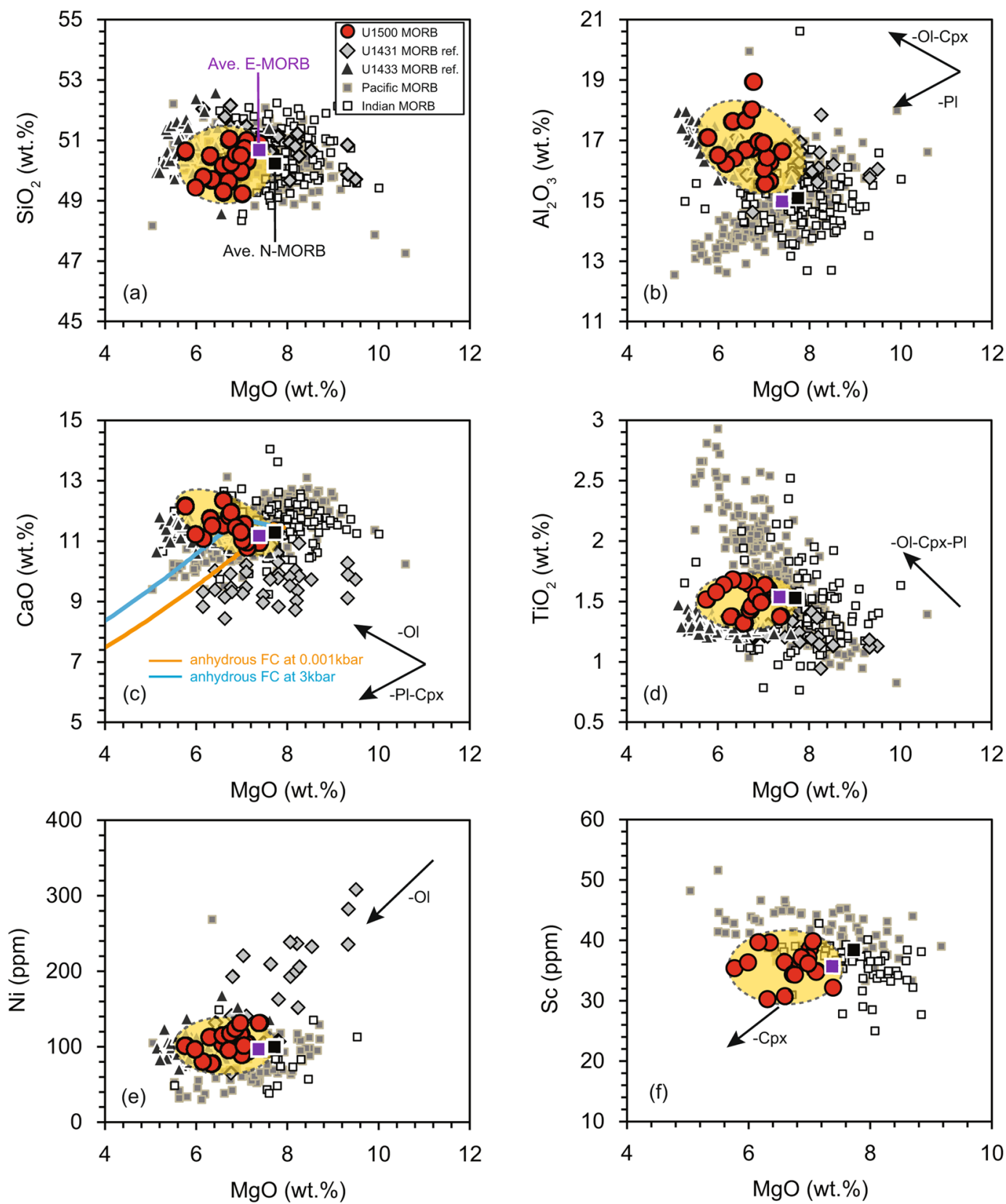

Figure 2. Plots of $\mathrm{SiO}_{2}(\mathbf{a}), \mathrm{Al}_{2} \mathrm{O}_{3}(\mathbf{b}), \mathrm{CaO}(\mathbf{c}), \mathrm{TiO}_{2}(\mathbf{d}), \mathrm{Ni}(\mathbf{e})$, and $\mathrm{Sc}(\mathbf{f})$ versus $\mathrm{MgO}$ for Site $\mathrm{U} 1500$ basalt samples. Fractional crystallization simulation by "Petrolog 3 " software ${ }^{59}$ is present in plot (c) as a function of olivine, plagioclase, and clinopyroxene removal for Site U1500 basalts at pressures of $0.001 \mathrm{kbar}$ and $3 \mathrm{kbar}$. Average N-MORB is used as the starting magma during the modeling. Reference data for basalt samples from Sites U1431 and U1433 are referred to references ${ }^{10,14}$. Average elemental data for N-MORB and E-MORB are from Gale et al. ${ }^{60}$. Data for global MORB (Pacific Ocean MORB and Indian Ocean MORB) are derived from Petrological Database (http://www.earthchem.org/petdb).

transitional MORB (T-MORB) on the MORB classification diagram, whereas Site U1431 basalts are identified as $\mathrm{N}$-MORB (Supplementary Fig. S2b). Site U1500 basalts have higher $\mathrm{Al}_{2} \mathrm{O}_{3}$ and $\mathrm{CaO}$ contents than those of average N-MORB with similar $\mathrm{SiO}_{2}$ and $\mathrm{TiO}_{2}$ contents (Fig. 2a-d). Ni and Sc contents of Site $\mathrm{U} 1500$ basalts are similar to those of average N-MORB (Fig. 2e,f). In comparison, Site U1431 basalts have lower $\mathrm{CaO}, \mathrm{TiO}_{2}$, and higher Ni contents compared with average N-MORB and Site U1500 basalts (Fig. 2c-e). The primitive-mantle-normalized trace-element patterns of Site U1500 basalts and average N-MORB are similar (Supplementary Fig. S3a) but differ from those of basalts from Sites U1431 and U1433 (Supplementary Fig. S3b). Furthermore, basalts from Sites U1431 and U1433 are characterized by positive Sr and Eu anomalies, but Site U1500 basalts lack of Sr and $\mathrm{Eu}$ anomalies (Supplementary Fig. S3). Nb content is correlated with the contents of the rare-earth elements (REEs; e.g., La and $\mathrm{Yb}$ ) (Supplementary Fig. S4a) and of the other high-field strength elements (HFSEs; e.g., Hf) (Supplementary Fig. S4b, c). In contrast, Nb is not correlated with some of the large-ion-lithophile elements 
(LILEs; e.g., Ba and U) (Supplementary Fig. S4d). In summary, Site U1500 basalts can be classified as MORB and represent oceanic crust formed during initial spreading of the SCS basin. Bulk major- and trace-element data are provided in Supplementary Table S1, and the details of methods are provided in the Supplementary Materials.

$\mathrm{CaO}$ contents of most of the olivines are $0.22-0.40 \mathrm{wt} \%$, higher than those of olivines from mantle xenoliths $(\mathrm{CaO}<0.1 \mathrm{wt} . \%)^{29,30}$. Ni abundance decreases with decreasing forsterite (Fo) content, as expected for olivine fractional crystallization (Supplementary Fig. S5a). The Fo content of olivine was plotted as a function of the $\mathrm{Mg} \#\left(100 *\right.$ molar $\left.\mathrm{Mg} /\left(\mathrm{Mg}+\mathrm{Fe}^{2+}\right)\right)$ of the host basalt (Supplementary Fig. S5b), assuming that the $\mathrm{Fe}^{3+} /$ total Fe ratio of the basalt is 0.1 . The $\mathrm{Fe}-\mathrm{Mg}$ exchange partition coefficients of olivine and basaltic melt $\left(\mathrm{K}_{\mathrm{D}}=(\mathrm{Fe} / \mathrm{Mg})^{\mathrm{ol} /}\right.$ $\left.(\mathrm{Fe} / \mathrm{Mg})^{\mathrm{liq}}\right)$ are well constrained by experiments to 0.30 at 1 atm and $0.31-0.34$ at $5-15 \mathrm{kbar}^{31}$. The olivine of our sample plots within the equilibrium field (Supplementary Fig. S5b). The major-element composition of olivine was analyzed by electron probe microanalysis (Supplementary Table S2), and the details of method are described in the Supplementary Materials.

\section{Discussion}

Effects of seawater alteration. Seawater alteration commonly affects the composition of MORB ${ }^{32,33}$, and its effects must be evaluated prior to interpretation of the geochemical data. The petrographic observations and loss on ignition (LOI) values $(<3 \mathrm{wt} . \%)$ indicate that seawater alteration was not extensive (Supplementary Fig. S1; Table S1). Furthermore, $\mathrm{K}_{2} \mathrm{O} / \mathrm{Nb}$, which is commonly used as a proxy for seawater alteration ${ }^{34}$, is not correlated with LOI, consistent with minimal seawater alteration, except for sample 57R-1-W107/110 and 75R-3W94/98 (Supplementary Fig. S6a). Some samples (e.g., 60R-2-W72/75, 65R-1-W132/140, and 79R-2-W139/143) have variable LILEs (e.g., U) on plots of LOI versus element content (Supplementary Fig. S6b), indicating that seawater alteration affected these LILEs. However, the LOI values are not correlated with $\mathrm{Ni}$, Ba, the REEs, or the HFSEs (Supplementary Fig. S6c-f), meaning that most elements were not affected by seawater alteration. Finally, the correlations amongst $\mathrm{Nb}$ and a range of elements also indicate that seawater alteration was not extensive (Supplementary Fig. S4). Elements affected by alteration are not well correlated with Nb because seawater alteration affects the concentrations of fluid-mobile elements more than it affects those of fluid-immobile elements ${ }^{34}$. The positive correlations among the fluid-immobile incompatible elements (e.g., $\mathrm{Nb}$ ) and the fluid-mobile incompatible elements (e.g., La) and the HFSEs (e.g., Hf and Th) indicate that seawater alteration did not affect the whole-rock composition significantly, except for samples 60R-2-W72/75 and 65R-1-W132/140 (Supplementary Fig. S4d). Therefore, we can conclude that the effect of seawater alteration was negligible for most of the samples.

Shallow magmatic processes. Effects of fractional crystallization. Basalts of Site U1500 are more enriched in the strongly incompatible elements (e.g., Ba and Nb) compared with basalts from Site U1431 and average N-MORB (Supplementary Fig. S3), which might be a consequence of fractional crystallization. Olivine fractionation increases the contents of the strongly incompatible elements, $\mathrm{SiO}_{2}$ and $\mathrm{Al}_{2} \mathrm{O}_{3}$, and decreases $\mathrm{MgO}$ content (Fig. 2b). Simultaneous fractionation of olivine and clinopyroxene increases the abundance of the strongly incompatible elements (e.g., $\mathrm{Ba}$ and $\mathrm{Nb}$ ) and decreases the contents of $\mathrm{MgO}, \mathrm{CaO}$, and $\mathrm{Ni}$ (Fig. 2c,e). Simultaneous fractionation of olivine and plagioclase increases the contents of the strongly incompatible elements and decreases $\mathrm{Al}_{2} \mathrm{O}_{3}$ content (Fig. 2b). Site $\mathrm{U} 1500$ basalts are characterized by decreasing in $\mathrm{MgO}$ and $\mathrm{Ni}$ contents (Fig. 2e) with increasing $\mathrm{Al}_{2} \mathrm{O}_{3}$ and $\mathrm{CaO}$ contents (Fig. 2b,c). The whole-rock $\mathrm{CaO} / \mathrm{Al}_{2} \mathrm{O}_{3}$ ratios and Sc abundance (Fig. 2f) remain nearly constant, and the basalts show slight negative correlation between $\mathrm{MgO}$ and $\mathrm{CaO}$ (Fig. 2c), suggesting that clinopyroxene fractionation was limited. In addition, the negative correlation between $\mathrm{MgO}$ and $\mathrm{Al}_{2} \mathrm{O}_{3}$ (Fig. 2b), and the lack of negative Eu and $\mathrm{Sr}$ anomalies (Supplementary Fig. S3) suggest that plagioclase fractionation did not take place. Fractional crystallization simulation has been implemented to model the $\mathrm{MgO}$ and $\mathrm{CaO}$ compositional variation as a function of olivine, plagioclase, and clinopyroxene removal for Site U1500 basalts at different pressures ( $0.001 \mathrm{kabr}$ versus $3 \mathrm{kbar}$; Fig. 2c). Because Ca is compatible in clinopyroxene, fractional crystallization of clinopyroxene could account for the decreasing $\mathrm{CaO}$ content. The difference in pressures $(0.001 \mathrm{kbar}$ versus $3 \mathrm{kbar})$ can determine the break point without changing the fate of $\mathrm{CaO}$ (Fig. 2c). Therefore, fractional crystallization of olivine occurred without fractionation of plagioclase or clinopyroxene. The strongly incompatible elements (e.g., HFSEs and REEs) are incompatible in olivine, whereas $\mathrm{Mg}$ and $\mathrm{Ni}$ are compatible, so the main effect of olivine fractional crystallization is to decrease the contents of $\mathrm{Mg}$ and $\mathrm{Ni}$ and increase the contents of the strongly incompatible elements. The basalt whole-rock compositions (incompatible trace element ratios) are suitable to infer compositional characteristics of their mantle source and those acquired by melt-rock interaction.

Effects of melt-rock interaction. Melt-rock interaction in the oceanic lithosphere commonly affects the majorand trace-element compositions of MORB formed at slow-spreading ridges prior to eruption ${ }^{35}$. Interaction between MORB melts and oceanic lithospheric mantle increases the $\mathrm{MgO}$ and $\mathrm{Al}_{2} \mathrm{O}_{3}$ contents of MORB, decreases its $\mathrm{SiO}_{2}$ content, and increases the contents of the strongly incompatible elements ${ }^{36,37}$. Melt-rock interaction in the lower oceanic crust can produce $\mathrm{MORB}$ with high $\mathrm{Al}_{2} \mathrm{O}_{3}$ and $\mathrm{CaO}$ contents, depleted strongly incompatible elements, and positive $\mathrm{Sr}$ and Eu anomalies ${ }^{38}$. Site $\mathrm{U} 1500$ basalts are characterized by higher $\mathrm{Al}_{2} \mathrm{O}_{3}$ and $\mathrm{CaO}$ contents than average N-MORB. However, Site U1500 basalts are also featured by lower MgO contents than average $\mathrm{N}-\mathrm{MORB}$ with similar $\mathrm{SiO}_{2}$ and $\mathrm{TiO}_{2}$ contents (Fig. 2a,d), and without any enrichment of strongly incompatible elements (Supplementary Fig. S3). The above geochemical variations cannot be interpreted by process of melt-rock interaction in oceanic lithospheric mantle. In addition, Site U1500 basalts do not have positive $\mathrm{Sr}$ and Eu anomalies, in contrast to the elemental anomalies as shown by Site U1433 basalts, which were affected by melt-rock interaction in the lower oceanic crust $^{39}$ (Supplementary Fig. S3a). Furthermore, melt-rock interaction influenced Site U1433 basalts are characterized by negative correlation between $\mathrm{MgO}$ and Eu/Eu*; however, 

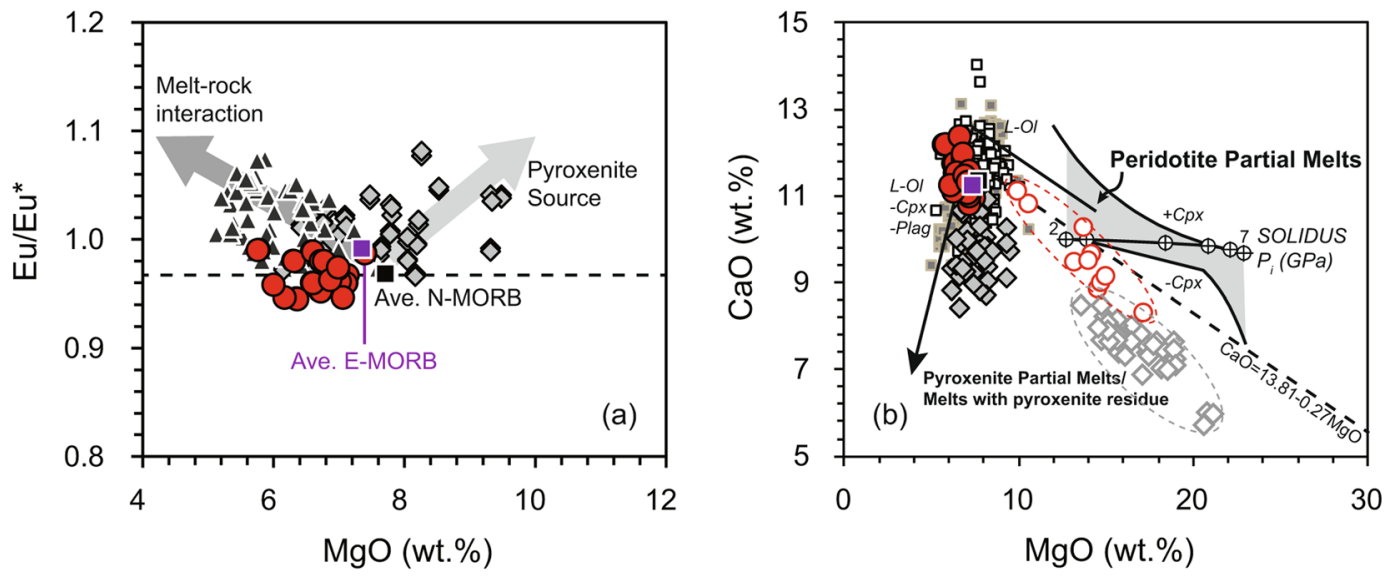

Figure 3. $\mathrm{Eu} / \mathrm{Eu}^{*}(\mathbf{a})$ and $\mathrm{CaO}(\mathbf{b})$ versus $\mathrm{MgO}$ for Site $\mathrm{U} 1500$ basalt samples. In (a), elemental anomalies are calculated as follows: $\mathrm{Eu} / \mathrm{Eu}^{*}=\mathrm{Eu}_{\mathrm{N}} /\left(\mathrm{Sm}_{\mathrm{N}} \times \mathrm{Gd}_{\mathrm{N}}\right)^{0.5}, \mathrm{~N}$ here stands for chondrite normalized. In $(\mathbf{b})$, the gray dotted line separating pyroxenite melts from peridotite melts is from Herzberg and Asimow ${ }^{53}$. Lavas with CaO contents lower than those defined by the dotted line are potential pyroxenite-bearing partial melts. Reference data for basalt samples from Sites U1431 and U1433 are referred to references ${ }^{10,14}$. In (b), the calculated primitive melt compositions for Site U1500 basalts are shown in red circles while calculated primitive melt compositions for Site U1431 are shown in grey diamonds. Average elemental data for N-MORB and E-MORB are from Gale et al. ${ }^{60}$. Data for global MORB (Pacific Ocean MORB and Indian Ocean MORB) are derived from Petrological Database (http://www.earthchem.org/petdb). Symbols are the same as in Fig. 2.

the $\mathrm{MgO}$ content of basalts of Site U1500 is not correlated with $\mathrm{Eu} / \mathrm{Eu}$ * (Fig. 3a), excluding a role for gabbro in their formation. The above observations together indicate that melt-rock interaction did not affect the geochemical compositions of the basalts of Site U1500.

Peridotite mantle source for Site U1500 basalts. The geochemistry of basalt can reflect the nature of its mantle source if the effects of shallow processes (e.g., seawater alteration, fractional crystallization, and melt-rock interaction) can be recognized or excluded. Here, a comparison of our new data with high-temperature experimental data and whole-rock and olivine geochemical data is used to infer that the mantle source lithology of Site U1500 basalts is spinel peridotite.

High-temperature experimental data. The contribution of mafic eclogite and pyroxenite to the source of basalts can be constrained by using the major-element compositions of the basalts and high-temperature experimental data ${ }^{40}$. Calcium is highly incompatible within olivine $\left(\mathrm{D}_{\mathrm{Ca}}^{\mathrm{Ol}}=0.02\right)^{41}$, but compatible within clinopyroxene $\left(\mathrm{D}_{\mathrm{Ca}}{ }^{\mathrm{Cpx}}=1.82-1.95\right)^{42}$. Therefore, the $\mathrm{CaO}$ content of a melt produced by low-degree partial melting of a pyroxenite source is lower than that of a melt derived from peridotite ${ }^{43}$. Primary melts of peridotite produced at pressures up to $7 \mathrm{GPa}$ have high $\mathrm{CaO}$ contents $(\sim 10 \mathrm{wt} . \%)$, irrespective of the fertility of the source peridotite $^{44}$. Site U1500 basalts and the calculated primitive melt compositions of Site U1500 basalts are plotted within the field of peridotite melt on a plot of $\mathrm{CaO}$ versus $\mathrm{MgO}$ (Fig. 3b). They have similar geochemical features to most of the Pacific and Indian Ocean MORB and average N-MORB (Fig. 3b). In comparison, at a given MgO content, Site U1431 basalts, which have been identified as the melting result of pyroxenite source ${ }^{10}$, have CaO contents lower than average N-MORB and are plotted within the field of pyroxenite melt. Therefore, the comparison with high-temperature experimental data indicate that Site U1500 basalts had a peridotite, rather than a clinopyroxene-rich, source.

Whole-rock and olivine geochemistry. Le Roux et al. ${ }^{45,46}$ showed that $\mathrm{Zn} / \mathrm{Fe}$ and $\mathrm{Fe} / \mathrm{Mn}$ do not fractionate among olivine, orthopyroxene, and melt, but fractionate strongly if garnet or clinopyroxene are involved in melting or crystallization. Davis et al. ${ }^{47}$ used experiments to constrain the partition coefficients of $\mathrm{Zn}, \mathrm{Fe}$, and $\mathrm{Mn}$ in partial melts of peridotite. Those authors demonstrated that values of $(\mathrm{Zn} / \mathrm{Fe}) \times 10^{4}>13$ and $\mathrm{Fe} / \mathrm{Mn}>62$ are characteristic of a non-peridotite source for natural OIBs, and that partial melts of eclogite or garnet pyroxenite have higher $\mathrm{Zn} / \mathrm{Fe}$ and $\mathrm{Fe} / \mathrm{Mn}$ values compared with partial melts of peridotite. The Hainan basalts are thought to be formed by melting of a pyroxenite source ${ }^{17}$. The values of $(\mathrm{Zn} / \mathrm{Fe}) \times 10^{4}$ and $\mathrm{Fe} / \mathrm{Mn}$ of Hainan basalts with $\mathrm{MgO}$ $>7.5$ wt.\% are 12.4-17.1 and 57.4-76.7, respectively, higher than the values for MORB and typical peridotite data (Fig. 4). In contrast, Site U1500 basalts are characterized by similar and lower $\mathrm{Zn} / \mathrm{Fe}$ and Fe/Mn values than those of average N-MORB and are plotted within the fields of MORB and peridotites ${ }^{45}$ (Fig. 4), consistent with a peridotite source for these basalts.

We used the composition of olivine to provide additional constraints on the source of Site U1500 basalts. Olivine is the first silicate mineral to crystallize from almost all mantle-derived magmas as they ascend towards the surface. The presence of pyroxenite or eclogite within the mantle source is recorded by olivine phenocrysts with high Ni contents ${ }^{48}$. Herzberg ${ }^{49}$ calculated the compositions of melts produced by fertile peridotite, and the composition of olivine fractionated from those melts (Supplementary Fig. S5a). The olivine Ni contents 

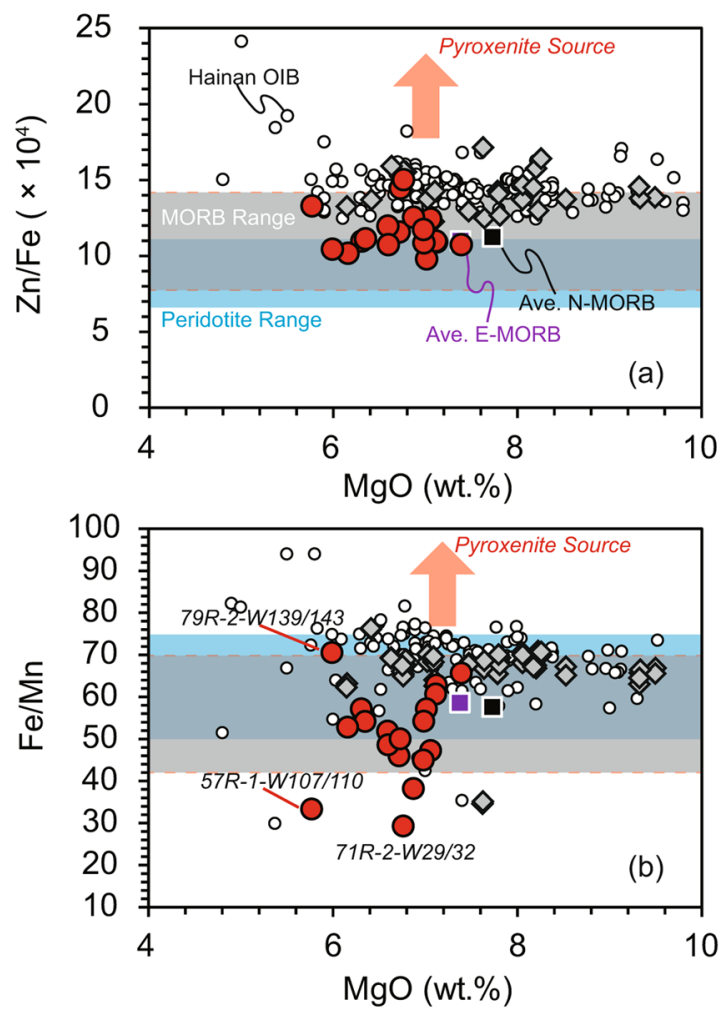

Figure 4. Relationship between (a) $\mathrm{Zn} / \mathrm{Fe}\left(\times 10^{4}\right)$, (b) Fe/Mn and $\mathrm{MgO}$ contents for Site U1500 basalt samples. Data of Site U1431 MORB are referred to Zhang et al. ${ }^{10,14}$, and data of Hainan OIB ${ }^{17,61,62}$ are collected for comparison which are represented by white circles. Average elemental data for N-MORB and E-MORB are from Gale et al. ${ }^{60}$. Fields for peridotite and global MORB are from Le Roux et al. ${ }^{45}$. Symbols are the same as in Fig. 2.

(Supplementary Fig. S5a) of MORB overlap with the calculated composition of olivine fractionated from melts of fertile peridotite, consistent with a peridotite-dominated mantle source for MORB. Olivine within Site U1431 basalts has higher Ni compared with average MORB and deviates significantly from the calculated composition of olivine fractionated from fertile peridotite melts (Supplementary Fig. S5a). These olivines are similar to those of Hawaiian and Hainan OIB, indicating that Site U1431 basalts were produced by melting of a mantle source that contained significant amounts of recycled oceanic crust (e.g., garnet pyroxenite $)^{10,48}$. In contrast, olivine within the basalts of Site U1500 has low Ni contents, similar to average MORB and the calculated composition of olivine fractionated from melts of fertile peridotite (Supplementary Fig. S5a).

The flat N-MORB-like primitive-mantle-normalized heavy REE pattern (Supplementary Fig. S3) further confirms a spinel peridotite mantle source. Then we can model the batch melting of a hypothetical mantle source in the spinel or garnet stability field by La/Yb-Sm/Yb compositions (Supplementary Fig. S7). Notably, for a given $\mathrm{La} / \mathrm{Yb}$, melting of garnet peridotite generates higher $\mathrm{Sm} / \mathrm{Yb}$ ratios (Supplementary Fig. S7). In comparison, all of Site U1500 basalts and most of Pacific and Indian Ocean MORB are located into the melting trend of spinel peridotite (Supplementary Fig. S7). Thus, the observed variations in the strongly incompatible element contents (Supplementary Fig. S3), as well as the good correlations between $\mathrm{Nb}$ and a range of incompatible elements (Supplementary Fig. S4), record the effect of olivine fractionation or variable degrees of partial melting of the spinel peridotite source.

Mantle potential temperature during initial spreading of the SCS. Models of mantle plumes based on the petrology and geochemistry of OIB require a heterogeneous mantle and a thermal anomaly ${ }^{49-51}$. Mantle potential temperatures $(T \mathrm{p})$ are used to constrain the magnitude of the thermal anomaly through comparisons between the Tp of OIB and MORB. The Tp is the temperature that the mantle would have if it were raised adiabatically to Earth's surface without melting ${ }^{52}$. In the thermal plume model, active thermal upwelling produces anomalously hot mantle, characterized by a non-zero excess temperature $\left(T_{e x}=T_{p}^{\text {hotspot }}-T_{p}{ }^{M O R}\right)$. Most OIB have $T_{\mathrm{ex}}$ values higher than those of MORB, with mean $T_{\mathrm{ex}}$ values of $175-195^{\circ} \mathrm{C}^{51}$. Therefore, thermally driven mantle plumes are common ${ }^{51}$, and $T \mathrm{p}$ can be used to determine the thermal state of the mantle and recognize the presence of mantle plumes.

The Tp can be calculated from the temperature of partial melting of the mantle which are derived from the calculated temperature of a primitive melt $t^{50,51,53}$. Most basalt thermometers are based on the assumption of a peridotite mantle source and require that melt compositions are close to those of primitive melts or underwent fractionation of olivine only. The olivine-liquid thermometer $\left(T^{\text {ol-liquid }}\right)$ does not require a specific lithology in the mantle source. In this study, we used the $\mathrm{SiO}_{2}$-based thermobarometer ${ }^{50}$, olivine-liquid equilibria based 


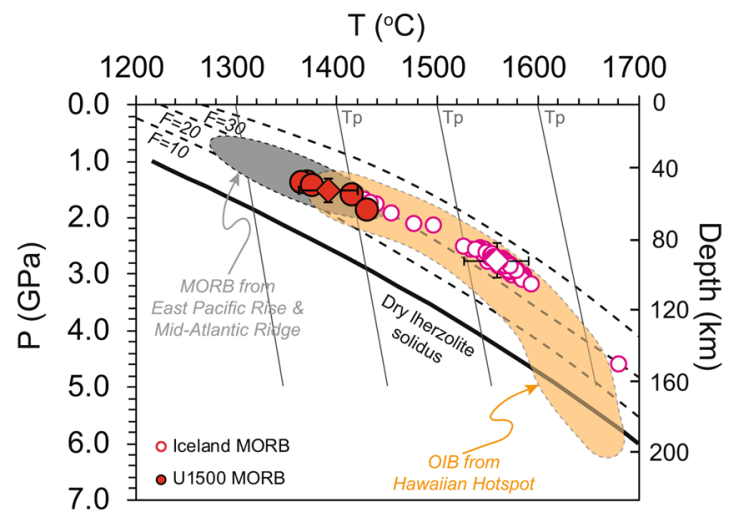

Figure 5. Melting temperatures and pressures calculated for Site U1500 basalt samples. Lherzolite solidus and melt fraction isopleths are from Katz et al..$^{63}$. Curved lines represent melting adiabats, near-vertical lines (grey) represent solid mantle adiabats, which are modified from Lee et al. ${ }^{50}$. Hawaiian hotspot source regions for shield and post-shield basalts are modified from Lee et al. ${ }^{50}$. Temperatures and pressures calculated for MORB from the East Pacific Rise and Mid-Atlantic Ridge are modified from Lee et al..$^{50}$, either. MORB from Iceland are derived from Petrological Database (http://www.earthchem.org/petdb) and calculated results are shown in Supplementary Table S3. During our calculations and for our samples, only fresh basalts with $\mathrm{MgO}>6.75$ wt. $\%$ were used. All magma compositions were corrected for olivine-fractionation up to olivine $\mathrm{Mg} \#$ of 0.9 (molar $\left.\mathrm{Mg}^{2+} /\left(\mathrm{Mg}^{2+}+\mathrm{Fe}^{2+}\right)\right)$.

thermometer ${ }^{51}$, and the mass balance based inverse model of PRIMELT3 MEGA software ${ }^{53}$ to estimate temperature of partial melting of mantle and then $T$ p. Samples affected by seawater alteration and those that recorded extensive fractional crystallization $(\mathrm{MgO}<6.75 \mathrm{wt}$ \%) were excluded. Details of how the temperatures were calculated can be referred in Supplementary Materials. Melting temperature as calculated from $\mathrm{SiO}_{2}$-based thermobarometer is $1390 \pm 29^{\circ} \mathrm{C}$ ( 1 standard deviation (SD)), melting temperature as calculated from olivine-liquid equilibria ranges from $1390^{\circ} \mathrm{C}$ to $1450^{\circ} \mathrm{C}$ (Supplementary Fig. S8), and melting temperature as calculated from PRIMELT3 MEGA software is $1367 \pm 38^{\circ} \mathrm{C}$. We further estimated Tp for Site U1500 basalts by $\mathrm{SiO}_{2}$-based thermobarometer and PRIMELT3 MEGA software, the average results of which vary from $\sim 1380^{\circ} \mathrm{C}$ to $\sim 1450^{\circ} \mathrm{C}$ (Fig. 5 and Supplementary Table S1). The consistency of the partial melting temperature and Tp values as calculated by different methods increases confidence in the validity of the calculations (Supplementary Table S1).

We compared the results for the basalts of Site U1500 with the calculated Tp of Iceland MORB, the global MORB array, and Hawaiian OIB (Fig. 5) by using $\mathrm{SiO}_{2}$-based thermobarometer. The advantage of using this method is that it can provide the calculations of temperature and pressure at the same time. Compared with PRIMELT3 MEGA software, $\mathrm{SiO}_{2}$-based thermobarometer considers the influence of physical factors during Tp estimation. In Fig. 5, the MORB Tp array represents the background upper-mantle temperature, whereas the Tps of the Iceland and Hawaii samples represent plume-affected mantle. The estimated Tp value of the basalts from Site U1500 is around $1380^{\circ} \mathrm{C}$, falling into zone of global MORB (Fig. 5). The melting temperature of basalts from Iceland is $1417-1593^{\circ} \mathrm{C}$ (Supplementary Table S3), with a mean of $1558 \pm 32^{\circ} \mathrm{C}(1 \mathrm{SD})$, the estimated Tp of which is close to the value of $\sim 1530^{\circ} \mathrm{C}$ calculated for Hawaiian OIB (Fig. 5). Thus, in summary, the Tp calculated from Site U1500 basalts is lower than the Tps of basalts from Iceland and Hawaii and close to normal MORB (Fig. 5). There was no thermal anomaly in the upper mantle when spreading of the SCS began.

\section{Implications}

The geochemical data indicate that spinel peridotite melting produced Site U1500 basalts. The Tp values show that the upper mantle that produced Site U1500 basalts had a similar thermal state to that of MORB-producing upper mantle. These conditions are significantly different from those inferred for basalts from Site U1431, which record a pyroxenite source and the presence of a thermal anomaly at the end of spreading ${ }^{10}$. Therefore, geochemical features attributable to plumes were absent during the initial stages of SCS spreading and increased towards the end of spreading ${ }^{10,13,14}$, meaning that the effects of mantle plumes can be neglected during initial spreading.

The geochemistry and Tp of MORB and OIB from the SCS can be used to constrain the evolution of the Hainan plume. The $25 \mathrm{Ma}$ MORB of the Kenting Mélange, southern Taiwan, have a depleted mantle-like isotopic composition, indicating that the Hainan plume did not contribute to the formation of oceanic crust at this time $^{13}$. In contrast, the crystallization temperatures of $16 \mathrm{Ma}$ basalts from Site U1431 are higher than those of $\mathrm{N}-M O R B^{12}$. The geochemical and isotopic characteristics of Site U1431 basalts indicate that their mantle source was pyroxenite that included an enriched EM2-like component ${ }^{14}$. Therefore, plume activity was exerting a strong effect on the SCS by $16 \mathrm{Ma}$. Ocean island basalts continued to form within the SCS basin and Hainan area after the cessation of SCS spreading $(\sim 15 \mathrm{Ma} \text { to present })^{17,19,27,54,55}$. The mantle source of these OIB is characterized by a thermal anomaly; the Tp of SCS OIB is $1647-1688^{\circ} \mathrm{C}$ and the Tp of Hainan OIB is $1468-1582^{\circ} \mathrm{C}^{9,17}$, and their $\mathrm{Sr}$, $\mathrm{Nd}$, and $\mathrm{Pb}$ isotope ratios record mixing between two end-members, one of which is an EM2-like component ${ }^{18}$. These data indicate that the Hainan plume affected the upper mantle after $\sim 25 \mathrm{Ma}$ and that plume-ridge interaction did not begin until $>8$ Myr after the initial spreading. 


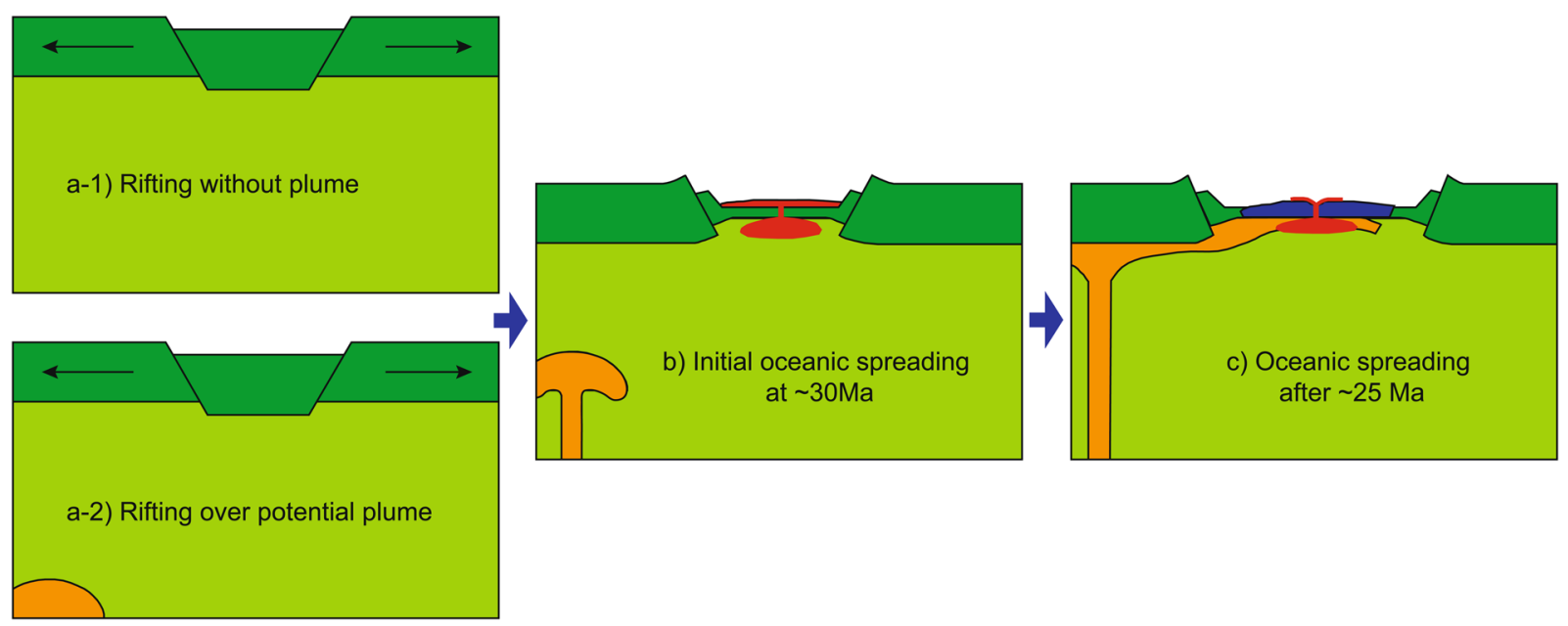

Figure 6. Cartoon showing the mantle dynamics of the SCS basin from continental rifting to oceanic crustal spreading. (a-1) Continental rifting without mantle plume activities in the mantle. (a-2) Continental rifting with potential mantle plume nearby but no influence. (b) In a scenario of rifting induced by tectonic forces, volcanism is the result of decompressing melting of the upwelling asthenosphere and postdates the main onset of rifting. Partial melting of the upper mantle might cause the suction of upper mantle and finally triggered the upwelling of deep hot materials or accelerated the upwelling of existing mantle plume nearby. (c) After transform from rifting to spreading, plume materials could be guided towards the thinning lithosphere (upsidedown drainage of Sleep ${ }^{57}$ ) causing plume-ridge interaction model after $\sim 25 \mathrm{Ma}$. The cartoon is modified from Buiter and Torsvik ${ }^{64}$.

We propose that the mantle beneath the SCS basin evolved as follows: (1) Prior to $~ 33 \mathrm{Ma}$, tectonic forces caused rifting and continental breakup without a mantle plume (Fig. 6a-1) or in the vicinity of an upwelling plume from the deep mantle (Fig. 6a-2). (2) At $33 \mathrm{Ma}$, rifting evolved into initial spreading. Partial melting of the upper mantle might have caused upwelling of deep hot material or accelerated upwelling of an existing mantle plume (Fig. 6b). (3) At $\sim 25 \mathrm{Ma}$, plume material began to interact with the thinning lithosphere in response to a reversal of flow patterns caused by spreading of the basin ${ }^{56,57}$ (Fig. 6c). Consequently, the rocks record plumeridge interaction after $\sim 25 \mathrm{Ma}$, indicating that plate tectonics, rather than a mantle plume, caused the continental rifting and initial spreading that formed the SCS. The primary cause of continental breakup and rapid transition to subsequent initial spreading was probably westward subduction and retreat of the Pacific Plate ${ }^{58}$. However, the mantle plume might have been a deep expression of continental breakup. If so, then the SCS could provide an excellent opportunity for research into rifting-induced mantle plumes.

\section{Methods}

Samples were first crushed into gravel-size chips. Clean chips were then pulverized in a corundum mill. Major element compositions of whole rocks were determined using a Thermo Scientific ARL 9900 X-ray fluorescence spectrometer (XRF) at the State Key Laboratory for Mineral Deposits Research, Nanjing University, China. Measurements of bulk rock trace element concentrations were completed at the Department of Geology, Northwest University, China. Trace elements were determined using an ELANG100DRC inductively coupled plasma mass spectrometer (ICP-MS) after the acid digestion $\left(\mathrm{HF}+\mathrm{HNO}_{3}\right)$ conducted in Teflon bombs. Trace elemental analyses of the USGS rock standards (BHVO-2, BCR-2, and AGV-2) are reported for comparison. Major element analysis and BSE imaging of minerals were carried out by EPMA (JEOL JXA-8230) equipped with four wavelength-dispersive spectrometers at the State Key Laboratory of Marine Geology, Tongji University. Details of methods are provided in the Supplementary Materials.

Received: 20 January 2020; Accepted: 28 April 2020;

Published online: 22 May 2020

\section{References}

1. Franke, D. Rifting, lithosphere breakup and volcanisms: comparison of magma-poor and volcanic rifted margins. Mar. Pet. Geol. 43, 63-87 (2013).

2. Tugend, J. et al. Re-appraisal of the Magma-Rich versus Magma-Poor Paradigm at Rifed Margin: consequences for breakup processes. AGU Fall Meeting Abstracts 2017AGUFM.T51B0463T (2017)

3. Holbrook, W. S. et al. Mantle thermal structure and active upwelling during continental breakup in the North Atlantic. Earth Planet. Sci. Lett. 190, 251-266 (2001).

4. Whitmarsh, R. B., Manatschal, G. \& Minshull, T. A. Evolution of magm-poor continental margins from rifting to seafloor spreading. Nature 413, 150-154 (2001).

5. Larsen, H. C., Mohn, G. \& Nirrengarten, M., the Expedition 367/368 Scientists. Rapid transition from continental breakup to igneous oceanic crust in the South China Sea. Nature Geosci. 11, 782-789 (2018).

6. Briais, A., Patriat, P. \& Tapponnier, P. Updated interpretation of magnetic anomalies and seafloor spreading stages in the South China Sea: implications for the Tertiary tectonics of Southeast Asia. J. Geophys. Res. 98, 6299-6328 (1993). 
7. Tapponnier, P., Peltzer, G., Le Dain, A. Y., Armijo, R. \& Cobbold, P. Propagating extrusion tectonics in Asia: new insights from simple experiments with plasticene. Geology 10, 611-616 (1982).

8. Xu, Y. G., Wei, J. X., Qiu, H. N., Zhang, H. H. \& Huang, X.-L. Opening and evolution of the South China Sea constrained by studies on volcanic rocks: Preliminary results and a research design. Chinese Sci. Bull. 57, 1863-1878 (2012).

9. Yan, Q. S. \& Shi, X. F. Olivine chemistry of Cenozoic basalts in the South China Sea and the potential temperature of the mantle. Acta Petrol. Sin. 24, 176-184 (2008).

10. Zhang, G.-L., Sun, W.-D. \& Seward, G. Mantle source and magmatic evolution of the dying spreading ridge in the South China Sea. Geochem. Geophys. Geosyst. 19, 4385-4399 (2018).

11. Taylor, B., \& Hayes, D. E. The tectonic evolution of the South China Basin in The Tectonic and Geologic Evolution of Southeast Asian Seas and Islands (ed. Hayes, D. E.) 89-104 (Geophysical Monograph, 1980).

12. Yang, F., Huang, X.-L., Xu, Y.-G. \& He, P.-L. Plume-ridge interaction in the South China Sea: Thermometric evidence from Hole U1431E of IODP Expedition 349. Lithos 324-325, 466-478 (2019).

13. Yu, M., Yi, Y., Huang, C. Y., Zhang, X. \& Santosh, M. Opening of the South China Sea and upwelling of the Hainan plume. Geophys. Res. Lett. 45, 2600-2609 (2018).

14. Zhang, G.-L. et al. Geochemical nature of sub-ridge mantle and opening dynamics of the South China Sea. Earth Planet. Sci. Lett. 489, 145-155 (2018).

15. Huang, J. \& Zhao, D. High-resolution mantle tomography of China and surrounding regions. J. Geophys. Res. 111, B09305, https:// doi.org/10.1029/2005JB004066 (2006).

16. Montelli, R., Nolet, G., Dahlen, F. A. \& Masters, G. A catalogue of deep mantle plumes: New results from finite-frequency tomography. Geochem. Geophys. Geosyst. 7, Q11007, https://doi.org/10.1029/2006GC001248 (2006).

17. Wang, X. C. et al. Temperature, pressure, and composition of the mantle source region of late Cenozoic basalts in Hainan Island, SE Asia: A consequence of a young thermal mantle plume close to subduction zones? J. Petrol. 53, 177-233 (2012).

18. Wang, X. C. et al. Identification of an ancient mantle reservoir and young recycled materials in the source region of a young mantle plume: Implications for potential linkages between plume and plate tectonics. Earth Planet. Sci. Lett. 377, 248-259 (2013).

19. Zou, H. \& Fan, Q. U-Th isotopes in Hainan basalts: Implications for sub-asthenospheric origin of EM2 mantle endmember and the dynamics of melting beneath Hainan Island. Lithos 116, 145-152 (2010).

20. Zhong, L. F. et al. ${ }^{40} \mathrm{Ar} /{ }^{39} \mathrm{Ar}$ dating of oceanic plagiogranite: Constraints on the initiation of seafloor spreading in the South China Sea. Lithos 302-303, 421-426 (2018).

21. Sun, Z., Stock, J., Klaus, A. \& the Expedition 367 Scientists. Expedition 367 Preliminary Report: South China Sea Rifted Margin. International Ocean Discovery Program, https://doi.org/10.14379/iodp.pr.367.2018 (2018).

22. Li, C.-F., Lin, J., Kulhanek, D. K. \& the Expedition 349 Scientists. Expedition 349 Preliminary Report: South China Sea tectonics. International Ocean Discovery Program, https://doi.org/10.14379/iodp.pr.349.2014 (2014).

23. Jian, Z., Larsen, H. C., Alvarez Zarikian, C. A. \& the Expedition 368 Scientists. Expedition 368 Preliminary Report: South China Sea Rifted Margin. International Ocean Discovery Program, https://doi.org/10.14379/iodp.pr.368.2018 (2018).

24. Li, C., Xu, X. \& Lin, J. \& the Expedition 349 Scientists. Ages and magnetic structures of the South China Sea constrained by deep tow magnetic surveys and IODP Expedition 349. Geochem. Geophys. Geosyst. 15, 4958-4983 (2015).

25. Barr, S. M. \& Macdonald, A. S. Palaeomagnetism, age, and geochemistry of the Denchai Basalt, northern Thailand. Earth Planet. Sci. Lett. 46, 113-124 (1979).

26. Ho, K. S., Chen, J. C. \& Juang, W. S. Geochronology and geochemistry of late Cenozoic basalts from the Leiqiong area, southern China. J. Asian Earth Sci. 18, 307-324 (2000).

27. Yan, Q., Shi, X. \& Castillo, P. R. The late Mesozoic-Cenozoic tectonic evolution of the South China Sea: A petrologic perspective. J. Asian Earth Sci. 85, 178-201 (2014).

28. Stock, J. M., Sun, Z., Klaus, A. \& the Expedition 367 Scientists. Site U1500. In Sun, Z. et al. South China Sea Rifted Margin. Proceedings of the International Ocean Discovery Program, 367/368: College Station, TX (International Ocean Discovery Program), https://doi.org/10.14379/iodp.proc.367368.104.2018 (2018).

29. Ren, Z. Y., Takahashi, E., Orihashi, Y. \& Johson, K. T. M. Petrogenesis of tholeiitic lavas from the submarine Hana Ridge, Haleakala Volcano, Hawaii. J. Petrol. 45, 2067-2099 (2004).

30. Thompson, R. N. \& Gibson, S. A. Transient high temperatures in mantle plume heads inferred from magnesian olivines in Phanerozoic picrites. Nature 28, 502-506 (2000).

31. Roeder, P. L. \& Emslie, R. F. Olivine-liquid equilibrium. Contrib. Mineral. Petrol. 29, 275-289 (1970).

32. Bienvenu, P., Bougault, H., Joron, J. L., Treuil, M. \& Dmitriev, L. MORB alteration: Rare-earth element/non-rare-earth hygromagmaphile element fractionation. Chem. Geol. 82, 1-14 (1990).

33. Verma, S. P. Seawater alteration effects on REE, K, Rb, Cs, Sr, U, Th, Pb and Sr-Nd-Pb isotope systematics of Mid-Ocean Ridge Basalt. Geochem. J. 26, 159-177 (1992).

34. Hart, S. R., Erlank, A. J. \& Kable, E. J. D. Sea floor basalt alteration: Some chemical and Sr isotopic effects. Contrib. Mineral. Petrol. 44, 219-230 (1974)

35. Eason, D. \& Sinton, J. M. Origin of high-Al N-MORB by fractional crystallization in the upper mantle beneath the Galapagos spreading center. Earth Planet. Sci. Lett. 252, 423-436 (2006).

36. Dygert, N., Liang, Y. \& Kelemen, P. B. Formation of plagioclase lherzolite and associated dunite-harzburgite-lherzolite sequences by multiple episodes of melt percolation and melt-rock reaction: An example from the Trinity Ophiolite, California, USA. J. Petrol. 57, 815-838 (2016).

37. Kelemen, P. B., Shimizu, N. \& Salters, V. J. M. Extraction of mid-ocean-ridge basalt from the upwelling mantle by focused flow of melt in dunite channels. Nature 375, 747-753 (1995).

38. Lissenberg, C. J. \& Macleod, C. J. A reactive porous flow control on mid-ocean ridge magmatic evolution. J. Petrol. 57, 2195-2220 (2016).

39. Yang, F., Huang, X.-L., Xu, Y.-G. \& He, P.-L. Magmatic processes associated with oceanic crustal accretion at slow-spreading ridges: Evidence from plagioclase in mid-ocean ridge basalts from the South China Sea. J. Petrol. 60, 1135-1162 (2019).

40. Lambart, S., Laporte, D. \& Schiano, P. An experimental study of pyroxenite partial melts at 1 and $1.5 \mathrm{GPa}$ : Implications for the major-element composition of Mid-Ocean Ridge Basalts. Earth Planet. Sci. Lett. 288, 335-347 (2009).

41. Leeman, W. \& Scheidegger, K. Olivine/liquid distribution coefficients and a test for crystal-iquid equilibrium. Earth Planet. Sci. Lett. 35, 247-257 (1977).

42. Pertermann, M. \& Hirschmann, M. M. Trace-element partitioning between vacancy-rich eclogitic clinopyroxene and silicate melt. Am. Mineral. 87, 1365-1376 (2002).

43. Herzberg, C. \& Asimow, P. D. Petrology of some oceanic island basalts: PRIMELT2. XLS software for primary magma calculation. Geochem. Geophys. Geosyst. 9; https://doi.org/10.1029/2008GC002057 (2008).

44. Herzberg, C. Petrology and thermal structure of the Hawaiian plume from Mauna Kea volcano. Nature 444, 605-609 (2006).

45. Le Roux, V., Lee, C. T. A. \& Turner, S. Zn/Fe systematics in mafic and ultramafic systems: implications for detecting major element heterogeneities in the Earth's mantle. Geochim. Cosmochim. Acta 74, 2779-2796 (2010).

46. Le Roux, V., Dasgupta, R. \& Lee, C. T. A. Mineralogical heterogeneities in the Earth's mantle: constraints from Mn Co, Ni and $\mathrm{Zn}$ partitioning during partial melting. Earth Planet. Sci. Lett. 307, 395-408 (2011). 
47. Davis, F. A., Humayun, M., Hirschmann, M. M. \& Cooper, R. S. Experimentally determined mineral/melt partitioning of first-row transition elements (FRTE) during partial melting of peridotite at $3 \mathrm{GPa}$. Geochim. Cosmochim. Acta 104, 232-260 (2013).

48. Sobolev, A. V. et al. The amount of recycled crust in sources of mantle-derived melts. Science 316, 412-417 (2007).

49. Herzberg, C. Identification of source lithology in the Hawaiian and Canary Islands: Implications for origins. J. Petrol. 52, 113-146 (2011).

50. Lee, C. T. A., Luffi, P., Plank, T., Dalton, H. \& Leeman, W. P. Constraints on the depths and temperatures of basaltic magma generation on Earth and other terrestrial planets using new thermobarometers for mafic magmas. Earth Planet. Sci. Lett. 279, 20-33 (2009).

51. Putirka, K. Excess temperatures at ocean islands: Implications for mantle layering and convection. Geology 36, 283-286 (2008).

52. McKenzie, D. \& Bickle, M. J. The volume and composition of melt generated by extension of the lithosphere. J. Petrol. 29, 625-679 (1988).

53. Herzberg, C. \& Asimow, P. D. PRIMELT3 MEGA.XLSM software for primary magma calculation: Peridotite primary magma MgO contents from the liquidus to the solidus. Geochem. Geophys. Geosyst. 16, 563-578 (2015).

54. Yan, Q. et al. Geochemistry and petrogenesis of volcanic rocks from Daimao Seamount (South China Sea) and their tectonic implications. Lithos 218-219, 117-126 (2015).

55. Zhang, G. L., Chen, L. H., Jackson, M. G. \& Hofmann, A. W. Evolution of carbonated melt to alkali basalt in the South China Sea. Nature Geosci. 10(3), 229-235 (2017).

56. Hill, R. I. Starting plumes and continental break-up. Earth Planet. Sci. Lett. 104, 398-416 (1991).

57. Sleep, N. H. Lateral flow and ponding of starting plume material. J. Geophys. Res. 102, 10001-10012 (1997).

58. Huang, C.-Y. et al. Potential role of strike-slip faults in opening up the South China Sea. Natl. Sci. Rev. nwz119; https://doi. org/10.1093/nsr/nwz119 (2019)

59. Danyushevsky, L. V. \& Plechov, P. Petrolog3: Integrated software for modeling crystallization processes. Geochem. Geophys. Geosyst. 12, Q07021, https://doi.org/10.1029/2011GC003516 (2011).

60. Gale, A., Dalton, C. A., Langmuir, C. H., Su, Y. \& Schilling, J. G. The mean composition of ocean ridge basalts. Geochem. Geophys. Geosyst. 14, 489-518 (2013).

61. Tu, K., Flower, M. F. J., Carlson, R. W., Zhang, M. \& Xie, G. Sr, Nd, and Pb isotopic compositions of Hainan basalts (south China): Implications for a subcontinental lithosphere Dupal source. Geology 19, 567-569 (1991).

62. Flower, M. F. J., Zhang, M., Chen, C.-Y., Tu, K. \& Xie, G. Magmatism in the South China Basin: 2. Post-spreading quaternary basalts from Hainan Island, South China. Chem. Geol. 97, 65-87 (1992).

63. Katz, R. F., Spiegelman, M. \& Langmuir, C. H. A new parameterization of hydrous mantle melting. Geochem. Geophys. Geosyst. 4; https://doi.org/10.1029/2002GC000433 (2003).

64. Buiter, S. J. H. \& Torsvik, T. H. A review of Wilson Cycle plate margins: A role for mantle plumes in continental break-up along sutures? Gondwana Res. 26, 627-653 (2014).

\section{Acknowledgements}

This research used samples provided by the International Ocean Discovery Program (IODP). Funding for this research was provided by the National Natural Science Foundation of China (41530964 and 41906051) and the National Key R\&D Program of China (2018YFE0202402). Reviews by two anonymous referees and editorial handling by Takeshi Kuritani are appreciated. We also thank Li-Hui Chen and Guo-Liang Zhang for discussion. Ling-Min Zhang, Wen-Li Xie and Ye Liu for their technique help during lab work. Xun Yu is sponsored by Shanghai Sailing Program (17YF1420300). The data for the present study are archived at Mendeley Data (https:// data.mendeley.com/datasets/hxrv2psyc6/1).

\section{Author contributions}

X.Y. designed this project and conducted the analysis. X.Y. and Z.L. analyzed the results and drafted the manuscript.

\section{Competing interests}

The authors declare no competing interests.

Additional information

Supplementary information is available for this paper at https://doi.org/10.1038/s41598-020-65174-y.

Correspondence and requests for materials should be addressed to X.Y. or Z.L.

Reprints and permissions information is available at www.nature.com/reprints.

Publisher's note Springer Nature remains neutral with regard to jurisdictional claims in published maps and institutional affiliations.

(c) (i) Open Access This article is licensed under a Creative Commons Attribution 4.0 International cc) License, which permits use, sharing, adaptation, distribution and reproduction in any medium or format, as long as you give appropriate credit to the original author(s) and the source, provide a link to the Creative Commons license, and indicate if changes were made. The images or other third party material in this article are included in the article's Creative Commons license, unless indicated otherwise in a credit line to the material. If material is not included in the article's Creative Commons license and your intended use is not permitted by statutory regulation or exceeds the permitted use, you will need to obtain permission directly from the copyright holder. To view a copy of this license, visit http://creativecommons.org/licenses/by/4.0/.

(C) The Author(s) 2020 